\title{
On the Improvement of China's Legal System of Foreign Direct Investment
}

\author{
Shu-Xue Jia ${ }^{1}$ \\ ${ }^{1}$ Law School of Qingdao University of Science and Technology, China \\ Correspondence: Shu-Xue Jia, Law School of Qingdao University of Science and Technology, Qingdao City \\ 266061, Shandong Province, China. Tel: 86-137-0895-9311. E-mail: jiashuxue@deheng.com.cn
}

Received: August 12, 2015 Accepted: August 21, 2015 Online Published: November 29, 2015

doi:10.5539/jpl.v8n4p293 URL: http://dx.doi.org/10.5539/jpl.v8n4p293

\begin{abstract}
China has not enacted unified foreign direct investment code, and the legal system of foreign direct investment is composed of separate laws and numerous regulations and rules at both national and local level. The establishment of all foreign investment enterprises in China is subject to examination and approval of relevant authorities, only after which enterprises can be registered. The operation duration of equity joint ventures, contractual joint ventures and solely foreign-founded enterprises shall comply with relevant provisions of Chinese laws. The operation duration and disillusion of foreign-invested stock joint limited companies are subject to Chinese Company Law. The 2-track legislation model, under which foreign investment enterprises and domestic enterprises are governed by different laws and regulations, caused conflicts among different laws and difficulties in application of laws. To overcome the defaults China must enact unified law on foreign direct investment.
\end{abstract}

Keywords: foreign direct investment, joint venture, legislative model

\section{Preface}

China so far has not enacted unified Foreign Direct Investment Code. The legal system of foreign direct investment (hereinafter referred to as "FDI") is constituted of a series of individual laws and supporting regulations and rules, of which the core is composed of the Law of Chinese-foreign Equity Joint Venture, the Law of Chinese-foreign Contractual Joint Venture, the Law of Foreign-founded Enterprise ${ }^{(1)}$ and three corresponding Regulations on implementation of these three basic laws. Besides, some other regulations or rules were also promulgated accordingly with regards to other issues beyond provisions of the above mentioned Laws and Regulations, such issues concerning the registration, labor, foreign currency, export \& import, and taxation etc.,

Compared with that of most other nations, China's FDI legal system has two typical characteristics as follows:

1. Two-track legislation model. In China, domestic enterprises and foreign investment enterprises are subject to total different laws and regulations. This legislation model is caused by the specific social environment pertaining to the early period of the opening-up and reform policy of China. At that time China took socialist public ownership as its economic foundation, in which state-owned enterprises and collective enterprises occupy a domination position. However, following the opening-up and reform policy the state also came to encourage and protect the development of private economy. Various forms of ownership led China's economic legislation to a so called two-track model suitable to the situation of that time.

2. Legislate respectively according to enterprise forms. Considering that equity joint venture is the internationally universal and normative form for foreign investment, China firstly enacted the Law of Chinese-foreign Equity Joint Venture ${ }^{(2)}$ at the beginning of its opening-up and reform in light of international experience. But in practice of the opening-up policy it showed that Chinese investors (mostly in Guangdong Province and Fujian Province) more like to adopt the form of contractual joint venture, especially with investors from Hong Kong and Macao. The number of contractual joint ventures was much more than that of equity joint

\footnotetext{
(1) These three laws are jointly known as "three-capital enterprise laws" or "foreign investment enterprise laws" in China.

${ }^{(2)}$ Enacted in 1979, and was revised for the second time in 2001
} 
ventures. So China accordingly promulgated the Law of Chinese-foreign Contractual Joint Venture. ${ }^{(3)}$ As regards solely foreign-founded enterprise, this traditional international investment form was prohibited in the beginning of China's opening-up and reform. However, alone with the deepening of the opening-up policy China came to realize that this enterprise form was not only attractive to investors but also benefit the host country, which, though without any founding from and any risk taken by the host country, can introduce foreign capital as well as high technology, increase employment and promote economic development. So this forbidden zone was broken up and foreign-founded enterprises were firstly allowed to establish in special economic zone, and then gradually spread to coastal cities and finally to the whole country. Under this situation the Law of Foreign-founded Enterprise ${ }^{(4)}$ were enacted. In 1995, the Ministry of Foreign Trade and Economy Cooperation enacted The Interim Provisions on Certain Issues Concerning Foreign-invested Joint Stock Limited Companies, which symbolize the official acknowledgement of foreign-invested joint stock limited company as a new form of foreign investment. Simultaneously, various other issues concerning taxation, foreign currency, market access and labor management etc. were regulated by a series of special legislations or rules.

From this legislation process we can see that China legislated for foreign investment respectively according to the forms of enterprise, taking into account China's actual situation thereof and relevant particular problems to be solved and. So the current basic laws on foreign investment enterprises are the Law of Sino-foreign Equity Joint Venture and its corresponding Regulations on Implementation, the Law of Sino-foreign Contractual Joint Venture and its corresponding Rules on Implementation, and the Law of Foreign-founded Enterprise and its Regulations on Implementation, which respectively apply to Sino-foreign equity joint ventures, Sino-foreign contractual joint ventures and solely foreign-founded enterprises. The content of three laws and their corresponding regulations or rules is composed of provisions of both investment law and enterprise law, with the focus on enterprise law provisions. ${ }^{(5)}$ So China's current law system regulating foreign direct investment actually is "foreign investment enterprise law" other than "foreign direct investment law". However, alone with the appearance of more forms of FDI, the model of legislating respectively according to enterprise forms couldn't suit the new situation any longer. Moreover, to legislate respectively on every form of FDI enterprise inevitably caused overlaps of and conflicts among the content of laws. Therefore, many Chinese scholars suggest to enact separate law on FDI to unify the existing various laws and regulations on foreign investment.

The above mentioned characteristics of China's foreign investment law caused conflicts among individual laws, which lead to great complication in the application of law. According to incomplete statistics, since opening-up and reform more than 200 national level laws or regulations on foreign investment, and over 1000 regulations or rules by departments or committees of the State Council and regional governments have been promulgated. Due to the numerous and jumbled content of the legal system, even to Chinese investors it is not an easy matter to achieve an accurate comprehension and application of foreign investment law of China, needless to say foreign investors. So firstly, the author is trying to summarize the most important content of China's current foreign investment legal system based on the aforesaid three basic laws and their corresponding regulations and rules, mainly focusing on investor qualification, corporate form, capital system, establishment, administration system and dissolution etc. of foreign investment enterprises, afterwards points out the defects of China's current legal system of FDI, and finally put forward proposals for the improvement of it.

\section{Framework of Legal System of Foreign Investment Enterprises}

As aforesaid, various forms of foreign investment enterprises came into being in China right alone with the step of China's opening-up and reform. In the beginning of opening-up and reform foreign investors invest mainly by establishing Chinese-foreign Equity Joint Ventures, Chinese-foreign Contractual Joint Ventures and solely foreign-founded enterprises. With development of the use of foreign capital, foreign investment forms gradually became diversified by some new forms like foreign-invested joint stock limited companies, BOT, and M\&A etc. This part is mainly to elaborate the most important issues like the legal status, organization forms, establishment procedures, capital system, management structure and disillusion etc. of Sino-foreign Equity Joint Ventures, Sino-foreign Contractual Joint Ventures, Solely Foreign-founded Enterprises and Foreign-invested Joint Stock Limited Companies.

\footnotetext{
${ }^{(3)}$ Enacted in 1988, and was revised in 2000

(4) Enacted in 1986, and was revised in 2000

${ }^{(5)}$ Wang Yumei: Study on the foreign direct investment system of China, Beijing: Law Press, 2003:35
} 


\subsection{Legal Status \& Organization Form of Foreign Investment Enterprises}

\subsubsection{Legal Status of Sino-foreign Equity Joint Ventures}

Sino-foreign Equity Joint Ventures refer to companies jointly set up in China by foreign companies, enterprises, economic organizations or individuals with Chinese companies, enterprises and economic organizations. ${ }^{(6)}$ According to this concept, qualified foreign investors consist of foreign companies, enterprises, other economic organizations and individuals. Meanwhile overseas Chinese, Hong Kong, Macao, Taiwan compatriots enjoy the same status as foreigners when they organize equity joint ventures in the mainland of China. However, Chinese participants are limited to approved and registered companies, enterprises and other economic organizations which have legal person qualifications, excluding individuals. Parties, government organs, administrative departments, non-governmental organizations, academic institutions, urban and rural individual industrial and commercial households and individual partnership, and moreover organizations which are not legal persons according to Chinese law ${ }^{(7)}$ are not qualified as such Chinese investors. ${ }^{(8)}$

A joint venture shall take the form of a limited liability company and shall obtain Chinese legal personality once it is approved and established. Both parties bear liability within the limit of their capital contribution subscribed, and the joint venture is liable for the debts within the scope of all its assets. ${ }^{(10)}$ As a limited liability company an equity joint venture differs from those limited liability companies subject to Chinese Company Law in the following two aspects. Firstly, equity joint ventures are foreign-oriented companies, in which partial founders are foreigners and they can make contribution in by means of foreign currency, foreign patent or trademark, and foreign equipment etc., which is much wider in scope than that prescribed for limited liability companies subject to the previous Chinese Company Law. Secondly, Chinese individuals may become shareholders of limited liability companies subject to Chinese Company Law, but they can't become shareholders of equity joint ventures which are subject to the aforesaid FDI laws.

\subsubsection{Legal Status and Organization Form of Sino-foreign Contractual Joint Ventures}

Chinese-foreign Contractual Joint Ventures refer to contractual enterprises jointly set up by foreign companies and other businesses with Chinese companies and other businesses. The qualifications of investors of Contractual Joint Ventures are similar to those of Equity Joint Ventures. The main difference from equity joint venture is that the rights and obligations of both parties are prescribed through contract agreed upon other than according to their capital contribution. The parties to the joint venture may specify in the contract the investment or cooperation conditions, distribution of profits or products, distribution of risk and loss, management method, and the ownership of property upon disillusion etc. So contractual joint ventures enjoy more flexibility than equity joint ventures in some issues like the organizational form, administrative organization and profit distribution etc.

With regards to the organizational form of Contractual Joint Venture there isn't clear stipulation in Chinese law besides that Contractual Joint Ventures may obtain Chinese legal personality if qualifications are met. ${ }^{(11)}$ Those who obtained Chinese legal personality are deemed limited liability companies in organization form. ${ }^{(12)}$ All parties bear liability within the limit of their capital contribution.

Some contractual joint ventures are similar to partnerships in their characteristics. They don't set up business entity with independent legal status therefore they don't have Chinese legal personality. All parties bear civil liabilities according to related stipulations of Chinese civil law, ${ }^{(13)}$ in details the related stipulations about unincorporated business associates in the General Rules of Civil Law of China. In such case both parties bear unlimited liability within the scope of the property they own according to the contract or proportion of capital contribution. ${ }^{(14)}$ Unincorporated contractual joint ventures are also required to be registered.

\subsubsection{Solely Foreign-founded Enterprises}

Foreign-founded enterprises, excluding branches of foreign companies and other businesses in China, hereby

\footnotetext{
(6) the Law of Chinese-foreign Equity Joint Venture, article 1

(7) the Circular on strictly Examining Qualification of the Chinese Party to an Equity Joint Venture, 1987,9

${ }^{(8)}$ Yao Zhenhai, Yu Jinsong: Lectures on Foreign Investment Enterprise ( the Second Version), Beijing: Law Press, 1997: 40

${ }^{(10)}$ the Law of Chinese-foreign Equity Joint Venture, article 2 and article 4.

(11) Law of Chinese-foreign Contractual Joint Venture, article 2

${ }^{(12)}$ Rules on the Implementation of the Law of Chinese-foreign Contractual Joint Venture, article 14

${ }^{(13)}$ Rules on the Implementation of the Law of Chinese-foreign Contractual Joint Venture, article 50

${ }^{(14)}$ General Principles of the Civil Law of the People's Republic of China, article 52
} 
refer to enterprises solely founded by foreign investors. ${ }^{(15)}$ Companies, other economic organizations and individuals from Hong Kong, Macao and Taiwan enjoy the same treatment as that for foreigners in case they set up private enterprises in Chinese mainland. ${ }^{(16)}$

If all requirements for being a Chinese legal person are met a foreign-founded enterprise obtains Chinese legal personality. ${ }^{(17)}$ A foreign-funded enterprise shall take limited liability company as its organizational form. Except otherwise approved. If the form of limited liability is adopted, the foreign investor shall be liable for the company within the scope of the capital he contributes. Those contractual joint ventures without Chinese legal personality may take organization forms of partnership or individual sole proprietorship enterprise. Investors of individual sole proprietorship enterprises shall bear unlimited liability for enterprise debt. In practice some small foreign-founded enterprise in business of restaurant, cattle breeding farm etc. usually adopt these two forms.

\subsubsection{Legal Status and Organization Form of Foreign-invested Joint Stock Limited Companies}

According to the Interim Provisions on Certain Issues Concerning the Establishment of Foreign-invested Joint Stock Limited Companies, a foreign-invested Joint Stock Limited Company refers to a corporation the capital of which is divided into shares with equal value, where the shareholders bear liability for the company to the extent of shares they subscribed, and the Chinese and foreign shareholders jointly hold the company's stock, of which the foreign shareholders subscribe and hold shall cover more than $25 \%$ of the company's registered capital. Such company is one of the forms of foreign investment enterprises and shall be governed by relevant laws and regulations of the state regulating foreign investment enterprises.

Like the other foreign investment enterprises with legal personality, foreign-invested joint stock limited companies have Chinese legal personality and are governed and protected by Chinese laws. With regards to issues not being prescribed by the Interim Provisions on Certain Issues Concerning the Establishment of Foreign-invested Joint Stock Limited Companies, Chinese Company Law shall be applied.

\subsection{Establishment of Foreign Investment Enterprises}

To establish foreign investment enterprises, investors must apply to the competent authorities, the Chinese Ministry of Foreign Trade and Economic Cooperation or local government for approval in advance. Essential documents to be submitted usually include the application form, report of feasibility study, agreement, contract, articles of association, legal representative certificate, list of candidates for directors etc. After receiving the approval for establishment the enterprise must apply for registration within a statutory period of time, and meanwhile obtain a business license. Besides, the industries invested in must comply with "the Provisions on Guiding the Orientation of Foreign Investment" and "the Catalogue of Guidance of Foreign Investment Industries", according to which foreign invested projects are divided into encouraged, restricted, permitted and prohibited ones.

To apply for establishing an equity joint venture, the parties shall submit to competent authority the Application, Agreement etc. and the other required documents. The competent authority shall make a decision on whether to approve or not within 3 months upon receiving the application documents. ${ }^{(20)}$ In case of being approved, the venture shall register with the industrial and commercial administration authority in one month upon receiving the approval, according to relevant regulations. The date of issuing business license shall be deemed to be the venture's establishment time. ${ }^{(21)}$

As for the establishment of Chinese-foreign Contractual Joint Ventures, the competent authorities shall make a decision on whether to approve or not within 45 days upon receiving the application documents, and the venture shall apply for registration within 30 days after being approved.

In the establishment of solely foreign-funded enterprises, the competent authority shall make a decision on whether to approve the application or not within 90 days upon receiving the application documents. The venture shall apply for registration within 30 days upon receiving the approval. The date on which the business license is issued shall be the date of its establishment.

According to article 6 of the Interim Provisions on the Establishment of Foreign-invested Joint Stock Limited Companies a foreign-invested Joint Stock Limited Company may be incorporated by means of promotion or share

\footnotetext{
${ }^{(15)}$ Law of Foreign-founded Enterprise, article 2

(16) Rules on the Law of Foreign-founded Enterprise, article 82

${ }^{(17)}$ Law of Foreign-founded Enterprise, article 8

${ }^{(20)}$ Regulations on the Implementation of the Law of Chinese-foreign Equity Joint Venture, article 8

${ }^{(21)}$ Regulations on the Implementation of the Law of Chinese-foreign Equity Joint Venture, article 9
} 
offer. Besides the requirements for promoters specified by the Company Law, there shall be at least one foreign shareholder for a company to be established by means of promotion.

After the promoters agree on the established the company, they may entrust one promoter to deal with all the establishment affairs according to procedures as follows:

1. Submit the application documents to the competent authorities of the provinces where the applicant is located;

2. After being examined by and with the consent of the competent authorities of the province, the documents shall be submitted through the competent authorities of the province to the foreign economic and trade departments of the same provinces. After obtaining the approval by the foreign economic and trade departments, the promoters then shall officially sign the agreement and the by-law of the company;

3. The signed agreement and the by-law shall be submitted to the Ministry of Foreign Trade and Economic Cooperation for examination and approval after being examined and approved by the foreign economic and trade departments of the provinces and the Ministry of Foreign Trade and Economic Cooperation shall make a decision on whether to approve or not within 45 days.

After the application for established is approved the other procedures concerning inaugural meeting, election of directors or supervisors and registration etc. are subject to relevant provisions of the Company Law.

\subsection{Capital System of Foreign Investment Enterprises}

\subsubsection{Capital of Chinese-foreign Equity Joint Ventures}

\subsubsection{Total Investment and Registered Capital}

Total investment of a joint venture refers to the total amount of basic construction capital and fluid capital according to the joint venture contract and the articles of association, including own capital and loan capital. Total investment is also called operating capital, which changes alone with the scale of business of the joint venture.

Registered capital refers to the total amount of capital registered at the registration authority, which shall be the total amount of capital contributions subscribed by all parties. ${ }^{(30)}$ There is no statutory minimum limit for the amount of registered capital of equity joint ventures, which is different from the relevant provisions of previous Chinese Company Law therein. ${ }^{(31)}$

To avoid too much loan capital, equity joint ventures shall abide by a statutory proportion of own capital to loan capital, which is indicated by the proportion of registered capital to total investment. The statutory proportions of registered capital to total investment to be abided by are as follows: 1) If the total amount of investment is less than 3 million dollars (including 3 million) registered capital shall cover no less than 7/10 of it, 2) If the total amount of investment is 3 million to 10 million dollars (including 10 million) registered capital should cover no less than $1 / 2$, 3) If the total amount of investment is 10 million to 30 million dollars (including 30 million) registered capital shall cover no less than $2 / 5$, and registered capital should be no less than 5 million dollars if the total investment is less than 12.5 million dollars, 4) If the total investment is more than 30 million dollars the registered capital shall cover no less than $1 / 3$, and if the total investment is less than 36 million dollars the registered capital shall be no less than 12 million dollars. ${ }^{(32)}$ If the equity joint venture can't implement the provisions of proportion above mentioned due to particular circumstances an approval shall be granted jointly by the Ministry of Commerce and the Administrative Bureau of Industry and Commerce. Chinese-foreign contractual joint ventures, foreign-founded enterprises, and enterprises set up by Hong Kong, Macao and Taiwan companies, enterprises, other economic organizations or individuals are subject to the provisions above mentioned with respect to the proportion of registered capital to total investment. ${ }^{(33)}$

\subsubsection{Proportion of Foreign Capital Contribution}

In the registered capital of Chinese-foreign equity joint venture the proportion of foreign investment shall be no less than $25 \%$, and there is no maximum limit for this proportion. This is because the aim of Chinese-foreign equity joint venture is to introduce more foreign capital to make up for the lack of domestic construction capital, which

\footnotetext{
${ }^{(30)}$ According to previous Company Law, registered capital refers to the total amount registered and already paid up by investors, not that of subscribed by investors.

(31) According to current Company Law the statutory minimum limit for registered capital is RMB30,000 for common limited liability companies, and RMB100,000 for one-person limited liability companies.

(32) Temporary Provisions on the Proportion of Registered Capital to Total Investment of Chinese-foreign Equity Joint Venture, article 3

${ }^{(33)}$ Interim Provisions on the Proportion of Registered Capital to Total Investment of Chinese-foreign Equity Joint Venture, article 4-7
} 
can't be achieved if the proportion of foreign investment is too low. However this is only the general principle. For particular type of enterprises there is still maximum limit for foreign investment, and Chinese parties must be at the holding or relatively holding position in such enterprises. ${ }^{(34)}$

\subsubsection{Forms and time limit of capital contribution}

All parties to a joint venture shall make their capital contribution subscribed for according to the joint venture contract in the form of own cash, kind without real rights for security established, industrial property rights, or proprietary technology etc. Investors, who make capital contribution in form of kind, industry property rights or proprietary technology, ${ }^{(35)}$ should present valid certificate of ownership and disposition rights. No party shall use loans, leasehold equipment and other property obtained in the name of the joint venture as capital contribution. No party is allowed to use property and equity of the joint venture or another party as guarantee for capital contribution. ${ }^{(36)}$

The joint venture contract shall prescribe a time limit for capital contribution to be made, in which all parties should pay up their capital contribution subscribed for. The capital contribution certificates issued by the joint venture shall be submitted to the original authority of examination and approval and the administrative authority for industry and commerce. If the joint venture contract prescribes that capital contributions should be made in a single full payment all parties shall pay up in 6 months upon issuance of the business license. If the joint venture prescribes that the capital contribution shall be made by installments the first installment shall not be less than $15 \%$, and shall be made within 3 months upon issuance of business license. ${ }^{(37)}$ Besides otherwise stipulated the maximum time limit for capital contribution by installments of foreign investment enterprises are as follows: 1) If registered capital is less than $\$ 500$ thousand(including 500 thousand), capital contribution shall be paid up in 1 year upon issuance of business license, 2) In case of $\$ 500$ thousand to 1 million (including 1 million), in one and a half year, 3) In case of $\$ 1$ million to 3 million (including 3 million), in 2 years. ${ }^{(38)}$

\subsubsection{Capital of Chinese-foreign Contractual Joint Ventures}

The forms of capital contribution and the proportion of registered capital to total investment of the contractual joint venture are similar to those of equity joint venture, so relevant provisions for equity joint venture can be referred to as reference. ${ }^{(39)}$ All parties may make contribution in cash, kind, land use right, industrial property right, non-patent technology and other property rights. ${ }^{(40)}$ However, the kind as capital contribution and the land use right and industrial property right as cooperation conditions shall not be evaluated, and also the proportion of capital contribution of both parties shall not be calculated. To Chinese parties there is no statutory requirement for proportion of capital contribution. After the capital contribution is paid up there should be a Chinese certified public accountant to make examination and issue an examination certificate of assets, according to which the joint venture issues certificate of capital contribution to both parties. A copy of the certificate of capital contribution shall be submitted to the authority of examination and approval and the administrative authority for industry and commerce. ${ }^{(41)}$

One of the biggest characteristics of contractual joint venture is that foreign investors may recover their investment ahead of time of expiration of the joint venture. If, both parties agree that all the fixed assets of the company will belong to the Chinese party upon the expiration of the expiration of the company.

In case the foreign party will recover its investment in advance of the expiration of the company as agreed by both parties before the payment of income tax, an application must be submitted to the financial and tax authorities for approval and both parties shall be liable for the debts of the company. ${ }^{(42)}$

\footnotetext{
(34) According to the Provisions Guiding the Orientation of Foreign Investment and the Catalogue of Guidance of Foreign Investment Industries, it must be the Chinese party who is at the holding or leading position in some industries like transportation, civil satellite, nuclear power construction, aircraft design and manufacture, publication and printing etc.

(35) The evaluation of tangible and intangible assets shall be subject to the Procedures on Administration of the Appraisal of Assets Invested by Foreign Investors

(36) Provisions on the Capital Contribution by Parties to Equity Joint Venture, article 2-3

${ }^{(37)}$ Provisions on the Capital Contribution by Parties to Equity Joint Venture, article 4

${ }^{\left({ }^{38}\right)}$ Circulars on Relevant Problems about the Administration of Examination and Registration of Foreign Investment Enterprises, article 6

(39) Interim Provisions on the Proportion of Registered Capital to Total Investment of Equity Joint Ventures, article 6

${ }^{(40)}$ Law of Chinese-foreign Contractual Joint Venture, article 8

${ }^{(41)}$ Rules on the Implementation of the Law of Chinese-foreign Contractual Joint Venture, article 22

${ }^{(42)}$ Law of Chinese-foreign Contractual Joint Venture, article 21
} 


\subsubsection{Capital of Solely Foreign-founded Enterprises}

Provisions concerning total investment and registered capital of foreign-founded enterprises are similar to those of equity joint ventures. The reduction, increase and assignment of registered capital shall be subject to approval of the competent authority and should be registered at the administrative authority for industry and commerce. So do with mortgage and assignment of property, rights and interests of the enterprise. ${ }^{(43)}$

The foreign investors may make capital contribution by means of convertible foreign currencies, machinery and equipment, or industry property rights and proprietary technology upon appraisal of their values. Upon approval of the authority of examination and approval, the foreign investors may also make capital contribution with profits in RMB that they get from any other enterprises established in China. The industrial property rights and proprietary technology to be contributed by the foreign investor shall be appraised and the total value of such contribution shall not exceed $20 \%$ of the enterprise' registered capital.

Foreign investors may make capital contribution in installments, the last of which shall be made in 3 years after the business license is issued. The first installment, being not less than fifteen percent of the capital contribution, shall be made within 90 days after the business license is issued. If the first installment is not made on time the approval certificate of the enterprise shall be invalid automatically. ${ }^{(44)}$

\subsubsection{Capital of Foreign-invested Joint Stock Limited Companies}

The minimum limit for registered capital of foreign-invested joint stock limited companies is RMB 30million which shall be the total amount of share capital registered and paid up. According to article 13 of the Interim Provisions on the Establishment of Foreign-invested Joint Stock Limited Companies, after the agreement and articles of association are approved a separate bank account shall be opened within 30 days and the shares subscribed shall be paid in one installment within 90 days after the approval certificate is issued. This is different with relevant provisions of Chinese Company Law concerning domestic joint stock companies. According to Chinese Company Law effective at that time, the minimum limit for registered capital of joint stock companies is RMB5million, and in case of establishment by means of promotion the registered capital is the total amount of share capital subscribed by all promoters, not the amount of share capital paid up by promoters, and the first installment shall not be less than $20 \%$ of the registered capital, with the left to be paid up within 2 years. In 2013 the minimum limit for registered capital for ordinary joint stock companies was removed by the latest revised Chinese Company Law, and so was that for ordinary limited liability companies.

\subsection{Dissolution of Foreign Investment Enterprise}

The duration of an equity joint venture is subject to the "Interim Provisions Concerning Contract Period of Chinese-Foreign Equity Joint Venture". For projects belonging to the "encouraged or permitted", the parties may select to prescribe the duration or not. However, as to industries as follows the parties to the joint venture shall prescribe the duration in contract: 1) service businesses, 2) land development and real estate, 3) prospecting and development of natural resources, 4) projects subject to investment restriction as stipulated by the state, 5) projects for which the duration shall be prescribed according to other laws and regulations of the state. ${ }^{(52)}$ For projects of which the duration must be prescribed in contract the duration shall be no more than 30 years, which shall be determined in accordance with the business type, investment amount, investment risk and time for recovering investment . For projects belonging to "encouraged and permitted" category of the state, the duration, if prescribed in contract, shall be no more than 50 years. For self-operated project of land development the duration shall not exceed the time limit of the land use right paid for. For projects of exploration and development of natural resources the duration shall be within a reasonable time limit after the approved exploitation reserves is depleted. ${ }^{(53)}$

The duration of a Chinese-foreign contractual joint venture shall be determined through consultation by both parties, and be stipulated in the contract of the venture. Because contractual joint venture usually involves foreign investors' request for recovering investment in advance the length of duration is in general based on the investment scale and the time for recovering investment by foreign investors. In general, if the time to recover investment is estimated to be 10 years the appropriate duration is $15-20$ years, and if this time is 8 years the appropriate duration

\footnotetext{
${ }^{(43)}$ Rules on the Implementation of the Law of Foreign-founded Enterprise, article 19-23

${ }^{(44)}$ Rules on the Implementation of the Law of Foreign-founded Enterprise, article 25-32

${ }^{(52)}$ Regulations on the Implementation of the Law of Chinese-foreign Equity Joint Venture, article, article 2

${ }^{(53)}$ Circular on Relevant Problems about Implementing the "Regulations on the Implementation of the Law of Chinese-foreign Equity Joint Ventures", item 2
} 
is $10-15$ years. In case it is agreed that the profit distribution and investment recovery are at the same time the duration is usually relative shorter or the same as the recovery time. ${ }^{(54)}$

The duration of a foreign-funded enterprise shall be prescribed by foreign investors in the application, and be approved by the competent authority. The duration shall be counted from the date of issuing business license. The investor shall submit an application to the examination and approval authority 180 days in advance if he wants to extend the duration. The authority shall make a decision whether to approve the extension or not within 30 days. After the extension is approved, the enterprise shall apply with the administrative authority for industry and commerce a registration change within 30 days upon receiving the approval. ${ }^{(55)}$

There is no limit for the duration of foreign-invested joint stock limited companies, the disillusion of which shall be subject to relevant provisions of Chinese Company Law.

\section{Defects of Chinese Legal System of Foreign Investment}

\subsection{Two-track Legislative Model Counter to Market Economy}

The two-track legislative model, where domestic enterprises and foreign enterprises are subject to total different laws and regulations respectively, is caused by the particular social environment pertaining to the early period of China's opening-up and reform. China takes socialist public ownership as its economic foundation, where state-owned enterprises and collective enterprises occupy a domination position. However, the opening-up and reform policy also requests the state to encourage and protect the development of private economy. This mixture of different ownerships constitutes the basis of China's economic legislation. Accordingly China adopted a legal system for foreign investment independent of that for domestic investment, which caused the aforesaid two-track legislation system. Laws for domestic enterprises, like "State-owned Industrial Enterprise Law", "Interim Regulations on Private Enterprises", "Regulations on Urban Collective Enterprises", "Regulations on Rural Collective Enterprises", "Individual Sole Proprietorship Enterprise Law" etc., do not apply to foreign-invested enterprises. Similarly, the legal provisions on issues concerning foreign-invested enterprises, like the establishment, corporate form, administrative management, taxation, and foreign currency etc. do not apply to domestic enterprises. Such legislation based on the particular social environment and conditions of that period was suitable to China's national situation thereof and it played an important role in promoting China's opening-up and reform with regards to attracting foreign investment and safeguarding national interests. ${ }^{(56)}$

However, alone with the deepening of China's economic restructuring, especially the establishment of market economy, the defects and negative effects of such a legislation model began to appear more and more obviously. For instance, the different provisions concerning taxation, foreign currency, import and export etc. make the domestic enterprises at a disadvantage, which drives some domestic enterprises to sham joint ventures by means of fraud, and meanwhile such unequal legal stipulations also dampened down the enthusiasm of foreign investors. Equal competition is the basic principle of market economy, but the two-track legislation model make domestic and foreign enterprises at unequal positions, which not only weakens the competitiveness of domestic enterprises, but also affects the investment confidence of foreign investors because it is counter to the requirements of national treatment. ${ }^{(57)}$

\subsection{Conflicts of Internal Legal Relations among Foreign Investment Laws}

As aforesaid, China's legislation for foreign investment has been undertaken respectively in accordance with the forms of different enterprises. Thus different enterprises are subject to different laws and regulations other than a unified code. The "Law of Chinese-foreign Equity Joint Venture", “ Law of Chinese-Foreign Contractual Joint Venture" and "Law of Foreign-founded Enterprises" constitute the core of China's foreign investment laws, among which the uncoordinated aspects are inevitable.

\subsubsection{Overlap of Provisions}

China's current foreign investment laws were enacted one by one according to the principle of "what is in need, what is legislated for" during the process of opening-up and reform. On one hand each law has strong relevance in resolving specific problems, but on the other hand the three laws have too many overlapped provisions. According to statistics the overlapped articles concerning the establishment procedures, means and time limit of capital

\footnotetext{
${ }^{(54)}$ Qi Duojun: Economic Organization Law of China, Beijing: Press of Political Science and Law University, 2003: 370

${ }^{(55)}$ Rules on the Implementation of the Law of Foreign-founded Enterprises, article 70-71

(56) Huang Hui: WTO and Legal Practice of International Investment, Jilin People's Press, 2001, page 293.

${ }^{(57)}$ Mu Yaping: "Huang Yong: To Reconstruct China's Foreign Investment Law to Adapt to the New Situation of WTO”, the World of Lawyer: 2001, 11, page 8
} 
contribution, procedures for dissolution and liquidation, taxation and foreign currency etc. Account for more than half of the contents of the three laws. This is a kind of serious waste of legislation reflecting the unreasonableness of China's foreign investment law system.

\subsubsection{Lack of Coordination among Three Laws}

The lack of coordination among three laws caused unequal treatments to foreign investment enterprises adopting different corporate forms. For instance, the time limits for examination and approval prescribed by three laws are different. The Law of Equity Joint Venture prescribes a time limit of 3 months, however that proscribed by the Law of Contractual Joint Venture is 45 days and the Law of Foreign-founded is 90 days. Moreover, the investment orientation prescribed by three laws is not in co-ordination. The Law of Chinese-foreign Equity Joint Venture doesn't involve this issue, and the Regulations for the Implementation of the Law of Chinese-foreign Equity Joint Venture prescribes that Chinese-foreign equity joint ventures may invest in 20 industries involving 6 areas, but does not clearly prescribed it is encouraged, restricted or permitted by the state with respect to each industry. The Law of Foreign-founded Enterprises ant the Rules for Implementation of the law of Foreign-founded Enterprises only prescribed the industries in which investments are restricted or prohibited by the state. The Law of Chinese-foreign Contractual Enterprises only prescribed that the state encourages the establishment of productive contractual join ventures which are export-oriented or technologically advanced. Moreover, some important issues concerning nationalization and requisition are prescribed the same in the Law of Chinese-foreign Equity Joint Ventures and the Law of foreign-founded Enterprises, but is not prescribed in the Law of Chinese-foreign Contractual Joint Ventures. All these aforesaid aspects not in coordination seriously affected the unity of China's foreign investment legislation system, and bring great negative impact on the authority and uniform enforcement of laws.

\subsection{Conflicts with related provisions of the Company Law}

\subsubsection{Different Provision on Withdrawing Capital}

According to the Law of Chinese-foreign Contractual Joint Venture, if both parties agreed in the contract that all the fixed assets of the contractual joint venture belong to Chinese party upon expiration of the contractual joint venture the foreign party may recover its investment ahead of time of the expiration of the contractual joint venture. On the contrary it is strictly prohibited to withdraw capital contribution by the Company Law, of which article 36 clearly prescribes: "Once a company is incorporated, its shareholders shall not withdraw their capital contribution".

\subsubsection{Difference in the Transfer of Investment}

Compared with the Company Law, foreign investment laws lay more restrictions on the transfer of capital contribution:

- According to Article 23 of the Regulations on the Implementation of the Law of the

Chinese-foreign Equity Joint Venture, the transfer of all or part of one party's shares to a third party other than the shareholders of the enterprise shall be subject to the consent of the other parties of the enterprise and the approval of the competent authority. Meanwhile the other parties to the venture shall enjoy preemptive right regarding the shares to be transferred.

- According to Article 10 of the Law of Chinese-foreign Contractual Joint Venture, the consent of

the other party and a report to the competent authority are required in case one party to the venture wants transfer all or part of his rights.

\section{- Article 23 of the Rules for the Implementation of the Law of Foreign-founded}

Enterprise required the approval by the competent authority with respect to the increase of the registered capital and the transfer of investment.

However, according to Article 72 of the Chinese Company Law, where a shareholder of a limited liability company intends to transfer his (her) shares to a third party, only the consent of over half of the other shareholders other than all of the company is required. Upon receiving the written notice of share transfer by the transferor, the other shareholders shall give a reply with 30 days as to agree to the transfer or not. Otherwise, they shall be deemed to have consented to such transfer. If over half of the other shareholders refuse to offer consent to the transfer of the shares, those who refused shall purchase the shares to be transferred. Otherwise they shall be deemed to have agreed to the transfer. In case more than half of the other shareholders disagree to such transfer, then, those shareholders disagreeing to the transfer shall purchase the equity to be transferred. Shareholders refusing to purchase shall be deemed to have agreed to the transfer. Under same conditions, the 
other shareholders shall have preemptive right.

It is thus clear that foreign investment laws prescribed more restrictions on the assignment of investment, which emphasized a principle of unanimous consent, preemptive right and governmental approval. On the contrary the relevant provisions on investment assignment of the Company Law are much more flexible. Investment transfer according to Company Law is not subject to the unanimous consent of the other shareholders and approval of government.

\subsubsection{Difference in Administration System}

Foreign-invested limited liability companies don't have to have shareholders' meeting, but only set up board of directors, which has dual power pertaining to the shareholders' meeting and the board of directors. However, domestic limited liability companies according to Company Law shall establish both the Shareholders' meeting and the board of directors.

According to laws on foreign-invested enterprises, the quorum of board of directors is $2 / 3$ of all directors or more ${ }^{(60)}$ however the Company Law prescribes a quorum of $1 / 2$ of all directors or more. ${ }^{(61)}$

\section{Reconstruction of China's Foreign Investment Legal System}

In China, due to the two-track legislative model, domestic enterprises and foreign investment enterprises are regulated by different laws and regulations. Thus, as "enterprises", they are subject to total different legal system only because the difference of their investors' nationality. Alone with the deepening of the reform of China's economic system and the establishment of market economic system, this legislative model has not been able to suit the new situation. Firstly, market economy requires equal status for all civil subjects, therefore civil and commercial laws shall uniformly apply to all market players, both domestic enterprises and foreign investment enterprises. Secondly, China's foreign investment laws contain not only provisions concerning investment law but also provisions concerning enterprise law, but the focus is on enterprise law prescribing enterprises' legal status, establishment procedures, internal organization, business scope and operation etc., and only a small section involves investment law content such as investment area, investment protection and investment incentive etc.

To improve the foreign investment legal system, the only way is to ultimately unify the legislations for both domestic investment and foreign investment. The framework of three laws on foreign investment is similar to that of Company Law, and the provisions of them also share lot similarities. Moreover, the Company Law was enacted on the basis of summarizing the practical experience of three laws on foreign investment enterprises, therefore it is more comprehensive and systematical. Currently the treatments enjoyed by foreign investment enterprises, especially those concerning taxation, registration foreign currency, financial management and labor management etc., are approaching those for domestic enterprises. All these legal relations and activities are uniformly subject to the Law of the People's Republic of China on Enterprise Income Tax, the Regulations of the People's Republic of China on the Administration of Company Registration, the Regulations of the People's Republic of China on the Administration of Foreign Currency, the Labor Law of the People's Republic of China etc. Following the improvement of relevant economic legal systems China should subject some issues regulated by the existing foreign investment laws, such as foreign enterprises' organizational form, establishment procedures, administration organism, disillusion and liquidation and legal liability etc. to the Company Law, Partnership Enterprise Law and Sole Proprietorship Law, and meanwhile promulgate a unified Law on Foreign Direct Investment to prescribe items concerning the concept of foreign investment, investment forms, foreign investment permission, investment area, capital corporation, examination and approval, national treatment, measures of encouragement and incentive, expropriation compensation, foreign investment protection etc. ${ }^{(62)}$

\section{References}

An, L. (2002). WTO Rules and Reconstruction of China's Foreign Investment Law. Study on Law and Commerce (Law Version), (3), 128.

Compile of Laws for Judicial Examination of 2008. (2008). Beijing: China Press of Legal System.

\footnotetext{
${ }^{\left({ }^{60)}\right.}$ Regulations on the Implementation of the Law of Chinese-foreign Equity Joint Ventures, item 2 of article 32;

Rules on the Implementation of the Law of Chinese-foreign Contractual Joint Ventures, item 2 of article 28.

${ }^{(61)}$ Company Law, article 112

${ }^{(62)}$ For instance, the Law of Foreign Investment Promotion of Korea mainly contains the following items: concept of foreigner, protection of foreign investment, guarantee of investment freedom, investment procedures, supporting measures for foreign investment, preferential treatment of foreign investment, areas of foreign investment, contract of technological introduction etc.
} 
Guo, F., \& Wang, J. (2000). On Amendments of Company Law. Beijing: Press of Law.

Li, G. H., \& Peng, X. H. (2002). Joining of WTO and Improvement of Foreign Investment Law. Shaoguan Collegez (Social Science), (11), 35.

Liu, J. H. (2008). the Science of Company Law. Beijing: Press of Beijing University.

Liu, Z., \& Liu, T. Y. (2002). Guidance for Foreign Taxation of China. Beijing: Press of Law.

Lu, J. X. (2001). Study on Problems of Foreign Investment Law of China. Beijing: Press of Law.

Mu, Y. P., \& Huang, Y. (2001). To Reconstruct China's Foreign Investment Law to Adapt the New Situation after Joining WTO. the World of Lawyer, (11), 8.

Qi, D. J. (2003). Economic Organization Law of China. Beijing, Press of University of Political Science and Law of China.

Shen, S. B., Wang, J., \& Jiao, J. H. (2000). International Commercial Law. Beijing: Press of University of Foreign Economy and Trade.

Wang, Y. M. (2003). Study on Legal System of Foreign Direct Investment of China. Beijing: Press of Law.

$\mathrm{Xu}, \mathrm{J}$. (2002). Introduction to Economic Law. Press of University of Foreign Economy and Trade.

Yao, M. Z., \& Yu, J. S. (1997). Lectures on Foreign Investment Enterprises (2nd ed.). Beijing: Press of Law.

Zhang, X. H. (2009). On Legal System of Foreign Investment of China. Journal of Jiangxi Administration College, (1), 51-53.

Zhao, X. L., \& Cao, J. (2002). Legal Services of Foreign Investment. Beijing: Zhongxin Press.

Zheng, P. C. (2001). On Impacts of Joining WTO on Foreign Investment Law. Journal of Hunan Institute of Politics and Law, (4), 32-36.

\section{Copyrights}

Copyright for this article is retained by the author(s), with first publication rights granted to the journal.

This is an open-access article distributed under the terms and conditions of the Creative Commons Attribution license (http://creativecommons.org/licenses/by/3.0/). 